\title{
PERILAKU MEMELIHARA KEBERSIHAN GIGI TIRUAN LEPASAN BERBASIS AKRILIK PADA MASYARAKAT DESA TREMAN KECAMATAN KAUDITAN
}

\author{
${ }^{1}$ David Adimulya Bagaray \\ ${ }^{2} \mathrm{Ni}$ Wayan Mariati \\ ${ }^{2}$ Michael A. Leman \\ ${ }^{1}$ Kandidat Skripsi Program Studi Pendidikan Dokter Gigi Fakultas Kedokteran \\ Universitas Sam Ratulangi Manado \\ ${ }^{2}$ Program Studi Pendidikan Dokter Gigi Fakultas Kedokteran Universitas Sam Ratulangi \\ Email:david.bagaray@gmail.com
}

\begin{abstract}
Behavioral to maintain denture hygiene is an important factor in the success of denture care because they have a close relationship with the knowledge, attitudes, and actions of the user. A poormaintenance denture hygiene could cause problems for oral health such as caries, gingivitis, stomatitis, xerostomia, candidiasis and periodontal disease, especially in the removable denture based acrylic user with the low level of education and income.This study aims to determine the behavior of maintaining the hygiene of removable denture based acrylic on population at Treman village Kauditan district.This research was a descriptive study with cross sectional approach. The population in this study was that the Treman villagers that uses removable denture based acrylic a total of 75 people. This study used total population as research subjects and measured using a questionnaire.In maintaining hygiene of removable denture based acrylic, Treman villagers have knowledge which was classified in sufficient category with a score of 103, an attitude which was classified in good category with a score of 130 , and act was classified in sufficient category with a score of 109.Behavior to maintain hygiene of removable denture based acrylic on population at Treman village Kauditan district was classified in sufficient category.
\end{abstract}

Keywords: Behavior, denture user, removable denture based acrylic.

\begin{abstract}
Abstrak: Perilaku memelihara kebersihan gigi tiruan merupakan faktor penting dalam keberhasilan perawatan gigi tiruan karena mempunyai hubungan erat dengan pengetahuan, sikap, dan tindakan pengguna gigi tiruan.Pemeliharaan kebersihan gigi tiruan yang kurang baik dapat menimbulkan masalah bagi kesehatan gigi dan mulut seperti karies, gingivitis, stomatitis, xerostomia, kandidiasis, dan penyakit periodontal, terutama pada pengguna gigi tiruan lepasan berbasis akrilik dengan tingkat pendidikan dan penghasilan yang rendah.Penelitian ini bertujuan untuk mengetahui perilaku memelihara kebersihan gigi tiruan lepasan berbasis akrilik pada masyrarakat desa Treman kecamatan Kauditan.Penelitian ini merupakan penelitian deskriptif dengan pendekatan cross sectional study.Populasi pada penelitian ini ialah seluruh masyarakat desa Treman yang menggunakan gigi tiruan lepasan berbasis akrilik yang berjumlah 75 orang. Penelitian ini menggunakan total populasi sebagai subjek penelitian dan diukur menggunakan kuesioner.Dalam memelihara kebersihan gigi tiruan lepasan berbasis akrilik, masyarakat desa Treman memiliki pengetahuan yang tergolong dalam kategori cukup dengan skor 103, sikap yang tergolong dalam kategori baik dengan skor 130, dan tindakan yang tergolong dalam kategori cukup dengan skor 109.Perilaku memelihara kebersihan gigi tiruan lepasan berbasis akrilik pada masyarakat desa Treman kecamatan Kauditan tergolong dalam kategori cukup.

Kata kunci: Perilaku, pengguna gigi tiruan, gigi tiruan lepasan berbasis akrilik.
\end{abstract}


Perilaku memelihara kebersihan gigi tiruan merupakan faktor penting dalam keberhasilan perawatan gigi tiruan. Perilaku memelihara kebersihan gigi tiruan mempunyai hubungan erat dengan pengetahuan, sikap, dan tindakan masyarakat dalam menggunakan gigi tiruan. Hal ini disebabkan karena pengetahuan, sikap, dan tindakan merupakan aspek penting dalam penilaian perilaku seseorang, sehingga perilaku sehari-hari dalam memelihara kebersihan gigi tiruan lepasan berbasis akrilik dapat diukur melalui ketiga aspek tersebut. Pengetahuan yang baik tentang cara memelihara kebersihan gigi tiruan akan menghasilkan sikap positif terhadap pemeliharaan kebersihan gigi tiruan, sehingga memberikan pengaruh yang baik terhadap kesehatan gigi dan mulut yang diwujudkan melalui tindakan. ${ }^{1,2}$

Pemeliharaan kebersihan gigi tiruan sangat berperan penting dalam proses perawatan gigi tiruan karena dapat membantu menjaga kekuatan, kestabilan, dan retensi gigi tiruan, serta menjaga kesehatan jaringan sekitar di dalam rongga mulut. Solusi pemakaian gigi tiruan lepasan berbasis akrilik sering menimbulkan masalah bagi kesehatan gigi dan mulut bila tidak diperhatikan kebersihan dan perawatannya. Masalah yang sering ditimbulkan akibat pemakaian gigi tiruan lepasan berbasis akrilik yaitu karies, stomatitis, gingivitis, xerostomia, kandidiasis, dan penyakit periodontal. Hal ini dapat terjadi akibat gigi tiruan selalu digunakan terus-menerus dan tidak dilepas, sehingga menyebabkan terjadinya penumpukan sisa makanan baik pada gigi asli maupun gigi tiruan dan menjadi faktor predisposisi terbentuknya plak yang merupakan tempat pertumbuhan bakteri dan jamur. ${ }^{3,4}$

Gigi tiruan lepasan berbasis akrilik merupakan gigi tiruan yang paling banyak digunakan saat ini yaitu lebih dari $95 \%$ dan terbuat dari bahan resin akrilik yang telah memenuhi syarat sebagai bahan basis gigi tiruan karena tidak bersifat toksik, tidak mengiritasi jaringan, mempunyai sifat fisik dan estetik yang baik, serta harga yang relatif murah. ${ }^{5,6}$ Gigi tiruan ini dipilih karena mudah pembuatannya, ringan, warnanya sama dengan gingiva, dan dapat dilakukan reparasi tanpa harus membuat gigi tiruan yang baru. Penggunaan gigi tiruan ini sudah banyak digunakan, namun terkadang tidak disertai dengan cara pemeliharaan yang baik sehingga menyebabkan adanya masalah pada gigi tiruan dan jaringan sekitar di dalam rongga mulut. ${ }^{4,6,7}$

Menurut survei yang dilakukan di Turki pada tahun 2006, saat pemasangan gigi tiruan pasien telah diberikan instruksi tentang cara memelihara kebersihan gigi tiruan, namun pasien sendiri yang tidak peduli dengan kebersihan gigi tiruan dan rongga mulut, sehingga memengaruhi perawatan gigi tiruan. ${ }^{8}$ Menurut penelitian yang dilakukan di Pakistan pada tahun 2010, faktor yang sangat memengaruhi keberhasilan perawatan gigi tiruan, khususnya dalam hal pemeliharaan kebersihan gigi tiruan, yaitu pendidikan. Seseorang dengan tingkat pendidikan yang tinggi akan lebih mengerti tentang cara memelihara gigi tiruan dan kesehatan rongga mulut daripada seseorang dengan tingkat pendidikan yang rendah. ${ }^{8}$ Hal ini didukung oleh penelitian yang dilakukan di Medan pada kelurahan Tanjung Rejo Kecamatan Medan Sunggal tahun 2012 bahwa tingkat pendidikan serta penghasilan masyarakat yang rendah merupakan faktor yang berpengaruh terhadap perilaku dan kebiasaan masyarakat dalam memelihara kebersihan gigi tiruan. ${ }^{9}$ Hal ini sangat memengaruhi keberhasilan perawatan gigi tiruan karena peran dari pasien itu sendiri merupakan faktor yang sangat penting.

Desa Treman terletak di kecamatan Kauditan, kabupaten Minahasa Utara dengan jumlah penduduk sebanyak 3439 jiwa.Menurut penelitian yang dilakukan pada tahun 2013 di desa tersebut, diperoleh data bahwa banyak masyarakat desa Treman yang menggunakan gigi tiruan lepasan 
berbasis akrilik. Hasil penelitian tersebut juga menunjukkan bahwa sebagian besar masyarakat desa Treman, khususnya pengguna gigi tiruan lepasan berbasis akrilik, memiliki tingkat pendidikan yang tergolong rendah. Selain itu, status pekerjaan dan penghasilan masyarakat desa Treman, khususnya pengguna gigi tiruan lepasan berbasis akrilik, juga masih tergolong menengah ke bawah karena memiliki pekerjaan sebagai petani, tukang ojek, dan pedagang kecil-kecilan. ${ }^{10,11} \mathrm{Hal}$ tersebut di atas sangat berpengaruh terhadap perilaku masyarakat khususnya pengguna gigi tiruan lepasan berbasis akrilik dalam memelihara kebersihan gigi tiruan.

Berdasarkan latar belakang tersebut, maka penulis merasa tertarik untuk melakukan penelitian yang berjudul "Perilaku Memelihara Kebersihan Gigi Tiruan Lepasan Berbasis Akrilik Pada Masyarakat Desa Treman Kecamatan Kauditan”.

\section{BAHAN DAN METODE}

Penelitian ini merupakan penelitian deskriptifdengan pendekatan cross sectional study, yang dilaksanakan di desa Treman Kecamatan Kauditan Kabupaten Minahasa Utara pada tahun 2014. Populasi pada penelitian ini yaitu seluruh masyarakat desa Treman yang menggunakan gigi tiruan lepasan berbasis akrilik yang berjumlah 75 orang dan menggunakan total populasi sebagai subjek penelitian. Kriteria inklusi yaitu pengguna gigi tiruan lepasan baik gigi tiruan sebagian lepasan maupun gigi tiruan penuh yang basisnya terbuat dari resin akrilik, bersedia dengan sukarela untuk dijadikan subjek dalam penelitian ini, dan bersifat kooperatif selama pengambilan data (bisa berkomunikasi dengan baik dan dapat bekerja sama saat pengambilan data dilakukan). Kriteria eksklusi yaitu Subjek penelitian yang tidak berada di tempat saat penelitian dilaksanakan.

Perilaku memelihara kebersihan gigi tiruan lepasan berbasis akrilik pada penelitian ini diukur menggunakan alat ukur kuesioner melalui tanya jawab kepada subjek penelitian dan diinterpretasi menggunakan skala Guttman, yaitu skala kumulatif yang digunakan pada pertanyaan dengan jawaban bersifat tegas dan konsisten terhadap permasalahan yang ditanyakan, seperti ya-tidak, benar-salah, setuju-tidak setuju, tahu-tidak tahu, dan sebagainya. Perilaku yang diukur meliputi pengetahuan, sikap, dan tindakan denganlima item pertanyaan pada setiap aspek perilaku tersebut.Skor dua diberikan untuk pertanyaan dengan jawaban tahu pada pertanyaan tentang pengetahuan, setuju pada pertanyaan tentang sikap, dan ya pada pertanyaan tentang tindakan. Skor satu diberikan untuk pertanyaan dengan jawaban tidak tahu pada pertanyaan tentang pengetahuan, tidak setuju pada pertanyaan tentang sikap, dan tidak untuk pertanyaan tentang tindakan.

Dengan demikian jumlah skor tertinggi dan terendah ialah sebagai berikut:

Jumlah skor tertinggi $2 \times 5 \times 75=750$

Jumlah skor terendah 1 × 5 x $75=375$

Dimana; Jumlah skor tertinggi $\{750\}$ dan terendah $\{375\}$ diperoleh dari hasil perkalian skor jawaban tertinggi $\{2\}$ dan terendah $\{1\}$ dengan jumlah pertanyaan pada setiap aspek perilaku $\{5\}$ dan dikalikan dengan banyaknya subjek penelitian $\{75\}$.

Data hasil pengukuran secara kontinum dapat dilihat pada skala berikut:

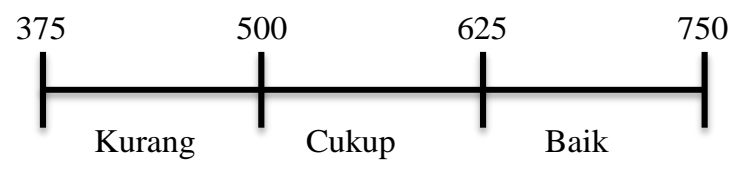

\section{HASIL PENELITIAN}

\section{Karakteristik subjek penelitian}

Jumlah subyek yang mengikuti penelitian ini yaitu sebanyak 75 orang (total populasi) yang telah sesuai dengan kriteria inklusi. Berikut ialah tabel distribusi karakteristik subjek penelitian:

Tabel 1. Distribusi karakteristik subjek penelitian berdasarkan jenis kelamin

Jenis Jumlah $\quad$ Persentase




\begin{tabular}{ccc}
\hline kelamin & $\begin{array}{c}\text { responden } \\
(\mathbf{n})\end{array}$ & $\mathbf{( \% )}$ \\
\hline Laki-laki & 22 & $29 \%$ \\
Perempuan & 53 & $71 \%$ \\
Total & 75 & $100 \%$ \\
\hline
\end{tabular}

Tabel 1 menunjukkan bahwa berdasarkan jenis kelamin, responden lakilaki berjumlah 22 orang dengan persentase sebesar $29 \%$ dan perempuan sebanyak 53 orang dengan

Tabel 2. Distribusi karakteristik subjek penelitian berdasarkan usia

\begin{tabular}{ccc}
\hline Usia & $\begin{array}{c}\text { Jumlah } \\
\text { responden } \\
(\mathbf{n})\end{array}$ & $\begin{array}{c}\text { Persentase } \\
(\%)\end{array}$ \\
\hline $20-30$ tahun & 2 & $3 \%$ \\
$31-40$ tahun & 6 & $8 \%$ \\
$41-50$ tahun & 18 & $24 \%$ \\
$51-60$ tahun & 13 & $17 \%$ \\
$61-70$ tahun & 25 & $33 \%$ \\
$71-80$ tahun & 8 & $11 \%$ \\
$81-90$ tahun & 3 & $4 \%$ \\
Total & 75 & $100 \%$ \\
\hline
\end{tabular}

Tabel 2 menunjukkan bahwa sebagian besar responden berada pada kelompok usia 61-70 tahun, yaitu sebanyak 25 responden dengan persentase sebesar $31 \%$, sedangkan jumlah terkecil berada pada kelompok usia 20-30 tahun, yaitu sebanyak dua responden dengan persentase sebesar $3 \%$.

Tabel 3. Distribusi karakteristik subjek penelitian berdasarkan pekerjaan

\begin{tabular}{ccc} 
Pekerjaan & $\begin{array}{c}\text { Jumlah } \\
\text { responden } \\
(\mathbf{n})\end{array}$ & $\begin{array}{c}\text { Persentase } \\
(\%)\end{array}$ \\
\hline PNS & 5 & $7 \%$ \\
Wiraswasta & 27 & $36 \%$ \\
IRT & 40 & $53 \%$ \\
Mahasiswa & 1 & $1 \%$ \\
Pensiunan & 2 & $3 \%$ \\
Total & 75 & $100 \%$ \\
\hline
\end{tabular}

Tabel 3 menunjukkan bahwa sebagian besar responden memiliki pekerjaan sebagai ibu rumah tangga (IRT) yaitu sebanyak 40 responden karena mayoritas sampel ialah perempuan dengan persentase sebesar 53\% dan jumlah terkecil ialah mahasiswa yaitu sebanyak satu responden dengan persentase sebesar $1 \%$.

Tabel 4. Distribusi karakteristik subjek penelitian berdasarkan pendidikan terakhir

\begin{tabular}{ccc}
\hline $\begin{array}{c}\text { Pendidikan } \\
\text { terakhir }\end{array}$ & $\begin{array}{c}\text { Jumlah } \\
\text { responden } \\
(\mathbf{n})\end{array}$ & $\begin{array}{c}\text { Persentase } \\
(\%)\end{array}$ \\
\hline SD & 17 & $23 \%$ \\
SMP & 19 & $25 \%$ \\
SMA & 36 & $48 \%$ \\
Perguruan & 3 & $4 \%$ \\
tinggi & 75 & $100 \%$ \\
Total & 75 \\
\hline
\end{tabular}

Tabel 4 menunjukkan bahwa tingkat pendidikan terakhir responden terbanyak berada pada jenjang pendidikan sekolah menengah atas (SMA) yaitu sebanyak 36 responden dengan persentase sebesar $48 \%$ dan jumlah terkecil berada pada jenjang pendidikan perguruan tinggi (PT) yaitu sebanyak tiga responden dengan persentase sebesar $4 \%$.

Tabel 5. Distribusi karakteristik subjek penelitian berdasarkan lama penggunaan gigi tiruan lepasan berbasis akrilik

\begin{tabular}{ccc}
\hline $\begin{array}{c}\text { Lama } \\
\text { penggunaan }\end{array}$ & $\begin{array}{c}\text { Jumlah } \\
\text { responden } \\
(\mathbf{n})\end{array}$ & $\begin{array}{c}\text { Persentase } \\
(\%)\end{array}$ \\
\hline$<1$ tahun & 4 & $5 \%$ \\
$1-5$ tahun & 16 & $21 \%$ \\
$6-10$ tahun & 17 & $23 \%$ \\
$>10$ tahun & 38 & $51 \%$ \\
Total & 75 & $100 \%$ \\
\hline
\end{tabular}

Tabel 5 menunjukkan bahwa sebagian besar responden telah menggunakan gigi tiruan selama $>5$ tahun yaitu sebanyak 55 responden dengan persentase sebesar $74 \%$ dan yang menggunakan gigi tiruan $<5$ tahun yaitu sebanyak 20 responden dengan persentase sebesar $26 \%$.

Tabel 6. Distribusi karakteristik subjek penelitian berdasarkan jenis gigi tiruan lepasan berbasis akrilik yang digunakan 


\begin{tabular}{ccc}
\hline $\begin{array}{c}\text { Jenis gigi } \\
\text { tiruan } \\
\text { lepasan }\end{array}$ & $\begin{array}{c}\text { Jumlah } \\
\text { responden } \\
(\mathbf{n})\end{array}$ & $\begin{array}{c}\text { Persentase } \\
(\%)\end{array}$ \\
\hline GTSL & 57 & $76 \%$ \\
GTP & 18 & $24 \%$ \\
Total & 75 & $100 \%$ \\
\hline
\end{tabular}

Tabel 6 menunjukkan bahwa pengguna gigi tiruan sebagian lepasan (GTSL) berjumlah 57 responden dengan persentase sebesar $76 \%$ yang merupakan responden terbanyak dan pengguna gigi tiruan penuh (GTP) berjumlah 18 responden dengan persentase sebesar $24 \%$ yang merupakan jumlah responden paling sedikit.
Perilaku memelihara kebersihan gigi tiruan lepasan berbasis akrilik pada masyarakat desa Treman Kecamatan Kauditan

Perilaku memelihara kebersihan gigi tiruan lepasan berbasis akrilik pada masyarakat desa Treman kecamatan Kauditan diukur menggunakan kuesioner. Pertanyaan dalam kuesioner terbagi dalam tiga aspek perilaku (pengetahuan, sikap, dan tindakan) dan berisi lima item pertanyaan pada masing-masing aspek tersebut. Berikut ialah hasil pengolahan data penelitian menurut ketiga aspek perilaku.

Tabel 7. Distribusi hasil penilaian pengetahuan masyarakat pengguna gigi tiruan lepasan berbasis akrilik di desa Treman Kecamatan Kauditan

\begin{tabular}{|c|c|c|c|c|}
\hline No & Pertanyaan & $\begin{array}{c}\text { Tahu } \\
\text { (n) }\end{array}$ & $\begin{array}{c}\text { Tidak } \\
\text { tahu } \\
\text { (n) }\end{array}$ & $\begin{array}{l}\text { Total skor } \\
\text { penilaian }\end{array}$ \\
\hline 1 & $\begin{array}{l}\text { Tahukah anda bahwa pemakaian gigi tiruan } \\
\text { berdampak buruk pada kebersihan rongga } \\
\text { mulut? }\end{array}$ & 32 & 43 & 107 \\
\hline 2 & $\begin{array}{l}\text { Tahukah anda bahwa gigi tiruan harus } \\
\text { dilepas pada malam hari sewaktu akan tidur } \\
\text { untuk mengurangi kemungkinan patah, } \\
\text { terutama bagi pengguna yang memiliki } \\
\text { kebiasaan jelek seperti gerinding gigi, dan } \\
\text { agar gigi tiruan tetap terjaga? }\end{array}$ & 23 & 52 & 98 \\
\hline 3 & $\begin{array}{l}\text { Tahukah anda bila gigi tiruan yang dilepas } \\
\text { dan tidak digunakan pada malam hari bila } \\
\text { tidak direndam dalam air dapat } \\
\text { mengakibatkan gigi tiruan mengerut } \\
\text { sehingga akan menyebabkan gigi tiruan } \\
\text { tidak pas pada mulut pengguna? }\end{array}$ & 22 & 53 & 97 \\
\hline 4 & $\begin{array}{l}\text { Tahukah anda bahwa membersihkan gigi } \\
\text { asli atau gigi sisa dan jaringan lunak mulut } \\
\text { (langit-langit, lidah, dan gusi) dapat } \\
\text { mencegah timbulnya jamur dan bau mulut? }\end{array}$ & 48 & 27 & 123 \\
\hline 5 & $\begin{array}{l}\text { Tahukah anda bahwa perlu dilakukan } \\
\text { kontrol ke dokter gigi setelah pemasangan } \\
\text { gigi tiruan agar kesehatan gigi dan mulut } \\
\text { pengguna gigi tiruan tetap terjaga? }\end{array}$ & 17 & 58 & 92 \\
\hline & Total skor & & & 517 \\
\hline
\end{tabular}

Tabel 7 menunjukkan bahwa berdasarkan lima pertanyaan yang diajukan tentang pengetahuan pada 75 responden, pertanyaan pertama memperoleh hasil 32 responden mengetahui bahwa penggunaan gigi tiruan mempunyai dampak yang buruk 
terhadap kebersihan rongga mulut, sedangkan 43 responden tidak mengetahuinya. Pertanyaan kedua memperoleh hasil 23 responden mengetahui bahwa gigi tiruan harus dilepas pada malam hari sewaktu akan tidur untuk mengurangi kemungkinan patah, terutama bagi pengguna yang memiliki kebiasaan jelek seperti gerinding gigi, agar gigi tiruan tetap terjaga, sedangkan 52 responden tidak mengetahuinya. Pertanyaan ketiga memperoleh hasil 22 responden mengetahui bahwa gigi tiruan yang dilepas dan tidak digunakan pada malam hari bila tidak direndam dalam air dapat mengakibatkan gigi tiruan mengerut sehingga akan menyebabkan gigi tiruan tidak pas pada mulut pengguna, sedangkan 53 responden tidak mengetahuinya. Pertanyaan keempat memperoleh hasil 48 responden mengetahui bahwa membersihkan gigi asli atau gigi sisa dan jaringan lunak mulut dapat mencegah timbulnya jamur dan bau mulut, sedangkan 27 responden tidak mengetahuinya. Pertanyaan kelima memperoleh hasil 17 responden mengetahui bahwa perlu dilakukan kontrol ke dokter gigi setelah pemasangan gigi tiruan, sedangkan 58 responden tidak mengetahuinya.

Berdasarkan hasil perhitungan jumlah skor, maka pengetahuan masyarakat tentang cara memelihara kebersihan gigi tiruan lepasan berbasis akrilik di desa Treman kecamatan Kauditan termasuk dalam kategori cukup dengan skor 517.

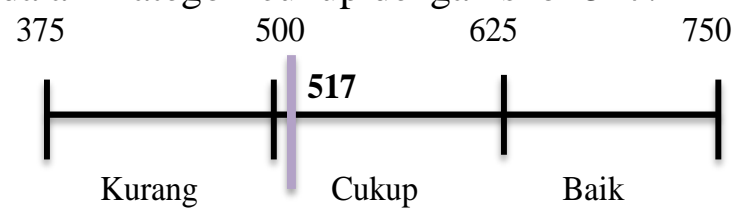

Tabel 8. Distribusi hasil penilaian sikap masyarakat pengguna gigi tiruan lepasan berbasis akrilik di desa Treman Kecamatan Kauditan

\begin{tabular}{clccc}
\hline No & \multicolumn{1}{c}{ Pertanyaan } & $\begin{array}{c}\text { Setuju } \\
\text { (n) }\end{array}$ & $\begin{array}{c}\text { Tidak } \\
\text { Setuju } \\
\text { (n) }\end{array}$ & $\begin{array}{c}\text { Total skor } \\
\text { penilaian }\end{array}$ \\
\hline 1 & $\begin{array}{l}\text { Setujukah anda bahwa gigi tiruan perlu } \\
\text { dijaga kebersihannya? }\end{array}$ & 72 & 3 & 147 \\
2 & $\begin{array}{l}\text { Setujukah anda bahwa gigi tiruan harus } \\
\text { dilepas pada malam hari sewaktu akan tidur } \\
\text { ? }\end{array}$ & 45 & 30 & 120 \\
3 & $\begin{array}{l}\text { Setujukah anda bahwa gigi tiruan yang } \\
\text { dilepas dan tidak dipakai pada malam hari } \\
\text { harus direndam dalam air ? }\end{array}$ & 44 & 31 & 97 \\
4 & $\begin{array}{l}\text { Setujukah anda bahwa gigi asli atau gigi } \\
\text { sisa dan jaringan lunak mulut (langit-langit, } \\
\text { lidah, dan gusi) juga perlu dijaga } \\
\text { kebersihannya? } \\
\text { Setujukah anda bahwa perlu dilakukan } \\
\text { kontrol ke dokter gigi setelah pemasangan } \\
\text { gigi tiruan? }\end{array}$ & 43 & 32 & 118 \\
\hline$\quad$ Total skor & 651 \\
\hline
\end{tabular}

Tabel 8 menunjukkan bahwa berdasarkan lima pertanyaan tentang sikap yang diajukan pada 75 responden, pertanyaan pertama memperoleh hasil 72 responden setuju bahwa gigi tiruan perlu dijaga kebersihannya, sedangkan tiga responden menjawab tidak setuju. Pertanyaan kedua memperoleh hasil 45 responden setuju bahwa gigi tiruan harus dilepas pada malam hari sewaktu akan tidur, sedangkan 30 responden menjawab tidak setuju. Pertanyaan ketiga memperoleh hasil 
44 responden setuju bahwa gigi tiruan yang dilepas dan tidak dipakai pada malam hari harus direndam dalam air, sedangkan 31 responden menjawab tidak setuju.Pertanyaan keempat memperoleh hasil 72 responden setuju bahwa gigi asli atau gigi sisa dan jaringan lunak mulut (langit-langit, lidah, dan gusi) juga perlu dijaga kebersihannya, sedangkan tiga responden menjawab tidak setuju. Pertanyaan kelima memperoleh hasil 43 responden setuju bahwa perlu dilakukan kontrol ke dokter gigi setelah pemasangan gigi tiruan, sedangkan 32 responden menjawab tidak setuju.

Berdasarkan hasil perhitungan jumlah skor, maka sikap masyarakat dalam memelihara kebersihan gigi tiruan lepasan berbasis akrilik di desa Treman kecamatan Kauditan termasuk dalam kategori baik dengan skor 651.

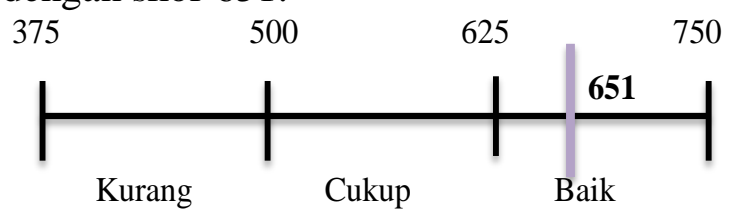

Tabel 9. Distribusi hasil penilaian tindakan masyarakat pengguna gigi tiruan lepasan berbasis akrilik di desa Treman Kecamatan Kauditan

\begin{tabular}{|c|c|c|c|c|}
\hline No & Pertanyaan & $\begin{array}{l}\text { Ya } \\
\text { (n) }\end{array}$ & $\begin{array}{l}\text { Tidak } \\
\text { (n) }\end{array}$ & $\begin{array}{l}\text { Total skor } \\
\text { penilaian }\end{array}$ \\
\hline 1 & $\begin{array}{l}\text { Apakah anda membersihkan gigi tiruan } \\
\text { setiap selesai makan? }\end{array}$ & 59 & 16 & 134 \\
\hline 2 & $\begin{array}{l}\text { Apakah anda melepas gigi tiruan pada saat } \\
\text { akan tidur malam? }\end{array}$ & 25 & 50 & 100 \\
\hline 3 & $\begin{array}{l}\text { Apakah anda merendam gigi tiruan dalam } \\
\text { air saat gigi tiruan tersebut dilepas dan tidak } \\
\text { dipakai ? }\end{array}$ & 18 & 57 & 93 \\
\hline 4 & $\begin{array}{l}\text { Apakah anda membersihkan gigi asli atau } \\
\text { gigi sisa dan jaringan lunak mulut (langit- } \\
\text { langit, lidah, dan gusi)? }\end{array}$ & 63 & 12 & 138 \\
\hline 5 & $\begin{array}{c}\text { Apakah anda melakukan kontrol kepada } \\
\text { dokter gigi setelah pemasangan gigi tiruan? } \\
\text { Total skor }\end{array}$ & 6 & 69 & $\begin{array}{c}81 \\
\mathbf{5 4 6} \\
\end{array}$ \\
\hline
\end{tabular}

Tabel 9 menunjukkan bahwa berdasarkan lima pertanyaan tentang tindakan yang diajukan pada 75 responden, pertanyaan pertama memperoleh hasil 59 responden membersihkan gigi tiruan setiap selesai makan, sedangkan 16 responden tidak melakukannya. Pertanyaan kedua memperoleh hasil 25 responden melepas gigi tiruan pada saat akan tidur malam, sedangkan 50 responden tidak melakukannya. Pertanyaan ketiga memperoleh hasil 18 responden merendam gigi tiruan mereka di dalam air saat gigi tiruan dilepas dan tidak dipakai, sedangkan 57 responden tidak melakukannya. Pertanyaan keempat memperoleh hasil 63 responden membersihkan gigi asli atau gigi sisa dan jaringan lunak mulut (langit-langit, lidah, dan gusi), sedangkan 12 responden tidak melakukannya. Pertanyaan kelima memperoleh hasil enam responden melakukan kontrol kepada dokter gigi setelah pemasangan gigi tiruan, sedangkan 69 responden tidak melakukannya.

Berdasarkan hasil perhitungan jumlah skor, maka tindakan masyarakat dalam memelihara kebersihan gigi tiruan lepasan berbasis akrilik di desa Treman kecamatan Kauditan termasuk dalam kategori cukup dengan skor 546.

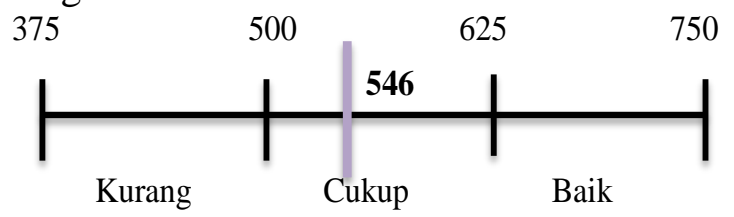


Tabel 10. Distribusi hasil penilaian perilaku memelihara kebersihan gigi tiruan lepasan berbasis akrilik pada masyarakat desa Treman kecamatan Kauditan

\begin{tabular}{ccc}
\hline No & Aspek perilaku & Skor \\
\hline 1 & Pengetahuan & 517 \\
2 & Sikap & 651 \\
3 & Tindakan & 546 \\
& Skor rata-rata & $\mathbf{5 7 1}$ \\
\hline
\end{tabular}

Tabel 10 menunjukkan bahwa berdasarkan hasil perhitungan skor rata-rata dari jumlah skor yang diperoleh pada setiap aspek perilaku, maka perilaku memelihara kebersihan gigi tiruan lepasan berbasis akrilik pada masyarakat desa Treman kecamatan Kauditan termasuk dalam kategori cukup dengan skor 571.

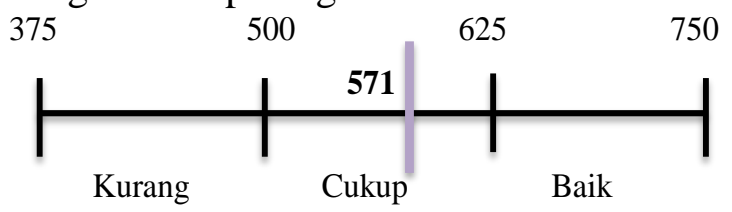

\section{BAHASAN}

Perilaku memelihara kebersihan gigi tiruan lepasan berbasis akrilik pada masyarakat desa Treman kecamatan Kauditan yang dinilai berdasarkan tiga aspek yaitu pengetahuan, sikap, dan tindakan memperoleh hasil bahwa pada aspek pengetahuan, masyarakat pengguna gigi tiruan lepasan berbasis akrilik di desa Treman memiliki pengetahuan yang masih tergolong dalam kategori cukup tentang pemeliharaan kebersihan gigi tiruan yang mereka gunakan. Pada pengetahuan responden tentang dampak buruk pemakaian gigi tiruan terhadap kebersihan rongga mulut memperoleh hasil yang masih kurang, dimana dari total 75 responden, hanya 32 yang tahu. Demikian juga dengan pengetahuan responden tentang pemeliharaan gigi tiruan, dimana hanya 23 responden yang mengetahui bahwa melepas gigi tiruan pada malam hari sewaktu akan tidur dapat mengurangi kemungkinan patah, terutama bagi yang memiliki kebiasaan jelek pada saat tidur, dan hanya 22 responden yang mengetahui bahwa merendam gigi tiruan di dalam air sewaktu dilepas dari mulut untuk mencegah gigi tiruan mengerut.

Ketiga hasil ini menunjukkan bahwa mayoritas pengguna gigi tiruan lepasan berbasis akrilik di desa Treman menggunakan gigi tiruan hanya sekedar menggunakan saja tanpa mengetahui dampak dari penggunaan gigi tiruan seperti memburuknya kebersihan mulut, meningkatnya akumulasi plak, bau mulut, karies, gingivitis, xerostomia, kandidiasis, dan penyakit peridontal, dan cara memelihara gigi tiruan yang mereka gunakan seperti melepas gigi tiruan sebelum tidur dan merendamnya dalam air untuk mencegah kemungkinan patah bagi pasien dengan kebiasaan jelek seperti gerinding gigi dan menghindari proses pengerutan yang menyebabkan gigi tiruan menjadi tidak pas di mulut. Berdasarkan hasil penelitian yang dilakukan oleh Olivia di kelurahan Bahu pada tahun 2013, menunjukkan bahwa mayoritas pengguna gigi tiruan lepasan menggunakan gigi tiruan hanya sekedar menggunakan tanpa mengetahui dampak, fungsi, dan manfaat dari pemakaian gigi tiruan. $^{12}$

Berbeda dengan pertanyaan pengetahuan lainnya, hasil yang baik ditunjukan oleh pertanyaan tentang pemeliharaan gigi asli yang masih tersisa serta jaringan lunak mulut. Pada pertanyaan ini, pengetahuan responden tentang membersihkan gigi asli yang masih tersisa dan jaringan lunak mulut seperti langit-langit, lidah, dan gusi untuk 
mencegah jamur dan bau mulut menunjukkan hasil bahwa mayoritas dari responden yaitu 48 responden mengetahui hal tersebut. Hal ini dikarenakan cara memelihara kebersihan gigi asli dan jaringan lunak mulut umumnya telah ditanamkan sejak dini dan sudah merupakan kebiasaan, sehingga walaupun tingkat pendidikan dan penghasilan responden tergolong rendah namun responden tetap mengetahui hal tersebut. Hal ini didukung juga oleh penelitian yang dilakukan di kelurahan Bahu, yaitu sebanyak $84 \%$ responden pengguna gigi tiruan lepasan dengan tingkat pendidikan yang rendah dan status ekonomi yang tergolong menengah ke bawah mengetahui bahwa membersihkan gigi asli yang masih tersisa dan jaringan lunak mulut dapat mencegah timbulnya jamur dan bau mulut. ${ }^{12}$

Pada pertanyaan tentang perlu dilakukannya kontrol ke dokter gigi setelah pemasangan gigi tiruan, memperoleh hasil bahwa mayoritas pengguna gigi tiruan lepasan berbasis akrilik tidak mengetahui hal tersebut yaitu sebanyak 58 responden dari jumlah total 75 responden. Mereka hanya mengetahui bahwa gigi tiruan setelah dipasang maka akan dipakai terus-menerus tanpa harus melakukan kontrol ke dokter gigi. Hal ini disebabkan karena kurangnya pemahaman masyarakat tentang informasi pentingnya memelihara kebersihan gigi tiruan, gigi asli, dan jaringan lunak mulut, serta perlunya dilakukan kontrol ke dokter gigi setelah pemasangan gigi tiruan. Masyarakat pada umumnya hanya sekedar tahu tanpa memahami manfaat dan tujuan serta dampak dari pemakaian gigi tiruan tersebut bagi kesehatan gigi dan mulut. ${ }^{13,14}$

Berdasarkan informasi yang juga didapatkan saat penelitian, sebagian besar pengguna gigi tiruan lepasan berbasis akrilik di desa Treman membuat gigi tiruannya pada tukang gigi sehingga informasi tentang pemeliharaan kebersihan gigi tiruan terkadang tidak didapatkan saat pemasangan gigi tiruan. Menurut penelitian yang dilakukan oleh Karniah di pulau Kodingareng, mayoritas pengguna gigi tiruan yang membuat gigi tiruan di tukang gigi $(54,9 \%)$, tidak pernah diberi instruksi dari tukang gigi tentang cara memelihara kebersihan gigi tiruan. Hal ini disebabkan oleh tingkat pendidikan masyarakat yang tergolong rendah, sehingga memengaruhi jenis pekerjaan serta kondisi ekonomi masyarakat yang menyebabkan sebagian besar responden lebih memilih membuat gigi tiruan pada tukang gigi dari pada dokter gigi. ${ }^{15}$ Pendidikan merupakan salah satu faktor yang memengaruhi pengetahuan. Seseorang dengan tingkat pendidikan yang tinggi akan lebih mengerti dan mempunyai daya serap yang baik terhadap informasi yang didapat sehingga pengetahuan yang diperoleh semakin baik. ${ }^{16}$

Pada aspek sikap, berdasarkan skor ratarata yang diperoleh menunjukkan hasil bahwa sikap masyarakat dalam memelihara gigi tiruan lepasan berbasis akrilik di desa Treman kecamatan Kauditan termasuk dalam kategori baik. Hasil ini menunjukkan bahwa pengguna gigi tiruan lepasan berbasis akrilik di desa Treman mempunyai kesadaran untuk berubah menjadi lebih baik dalam memelihara kebersihan gigi tiruan mereka.Salah satu alasan seseorang menunjukkan sikap yang ingin berubah atau menjadi lebih baik dalam hal kesehatan karena adanya suatu inovasi yang dapat memotivasi responden. Melalui inovasi yang diperoleh seperti program-program kesehatan atau sarana lain yang membantu responden dalam hal mendapatkan informasi tentang pemeliharaan kebersihan gigi tiruan serta kesehatan gigi dan mulut khususnya pada pengguna gigi tiruan dan mengadopsi nilai-nilai yang baik dari inovasi tersebut untuk melakukan perubahan. $^{16,17}$

Hasil yang baik ditunjukan oleh responden tentang perlunya menjaga kebersihan gigi tiruan lepasan berbasis akrilik.Sebanyak 72 responden setuju bahwa gigi tiruan harus dijaga kebersihannya, sedangkan hanya tiga responden yang tidak setuju mengenai hal ini. Kesadaran responden tentang pemeliharaan gigi tiruan menunjukkan hasil yang sedikit berbeda 
dimana terdapat 45 responden yang setuju untuk melepas gigi tiruan sewaktu akan tidur dan 30 responden tidak menyetujuinya. Hal serupa juga terjadi pada sikap responden tentang merendam gigi tiruan dalam air saat dilepas atau tidak dipakai.Hanya 44 responden yang setuju bahwa gigi tiruan yang dilepas atau tidak dipakai pada malam hari harus direndam dalam air, sedangkan 31 responden tidak menyetujuinya.Hal ini disebabkan karena masih kurangnya pemahaman responden tentang manfaat dan tujuan dari pemeliharaan gigi tiruan. Sebagian besar responden hanya mendengar dari lingkungan sekitar tentang melepas gigi tiruan pada malam hari saat akan tidur dan harus direndam di dalam air, namun tidak mengetahui bahwa gigi tiruan yang dilepas pada malam hari dan direndam dalam air bertujuan untuk mengurangi kemungkinan patah terutama pada pengguna yang memiliki kebiasaan buruk saat tidur seperti gerinding gigi, dan agar gigi tiruan tidak mengalami pengerutan yang dapat menyebabkan gigi tiruan tidak pas dimulut saat dipakai. ${ }^{12,14}$

Sikap responden dalam memelihara kebersihan gigi asli yang masih tersisa serta jaringan lunak mulut menunjukkan hasil yang baik dimana terdapat 72 responden yang menyetujuinya sedangkan hanya tiga responden yang tidak setuju.Hal ini menunjukkan adanya kesadaran responden tentang pentingnya menjaga kebersihan rongga mulut selama pemakaian gigi tiruan agar terhindar dari masalah kesehatan gigi dan mulut akibat kebersihan yang kurang dijaga.Sikap masyarakat tentang perlunya dilakukan kontrol ke dokter gigi setelah pemasangan gigi tiruan memperoleh hasil yang berbeda dimana terdapat 43 responden yang setuju dengan hal tersebut dan 32 responden tidak setuju. Hal ini disebabkan karena jarak tempuh tempat pelayanan kesehatan gigi dan mulut khususnya untuk pembuatan gigi tiruan cukup menyita waktu dan membutuhkan biaya yang tidak sedikit apabila berobat atau melakukan kontrol ke dokter gigi. ${ }^{11,18}$
Tindakan atau perbuatan nyata, yang merupakan wujud dari aspek pengetahuan dan sikap.Hasil penelitian yang didapatkan pada aspek tindakan menunjukkan bahwa tindakan memelihara kebersihan gigi tiruan lepasan berbasis akrilik pada masyarakat desa Treman kecamatan Kauditan tergolong dalam kategori cukup. Hasil ini sesuai dengan pengetahuan masyarakat desa Treman tentang cara memelihara gigi tiruan lepasan berbasis akrilik yang masih tergolong cukup.

Tindakan responden dalam memelihara gigi tiruan memeperoleh hasil yang masih kurang, dimana hanya sebagian kecil dari responden yang melepas gigi tiruannya pada saat akan tidur malam yaitu sebanyak 25 responden, sedangkan 50 responden tidak melakukannya. Hasil tersebut tidak jauh berbeda dengan tindakan responden dalam merendam gigi tiruan di dalam air saat gigi tiruan dilepas atau tidak dipakai yang hanya dilakukan oleh 18 responden sementara 57 responden tidak melakukannya. Hasil yang sama juga diperoleh pada penelitian yang dilakukan di Universitas Sao Paulo Brasil yang menunjukkan bahwa sebagian besar responden yaitu sebesar $58,49 \%$ tidur menggunakan gigi tiruan. ${ }^{19} \mathrm{Hal}$ ini disebabkan oleh kurangnya pengetahuan responden tentang resiko yang dapat terjadi akibat gigi tiruan yang tidak dilepas dan tidak direndam di dalam air.

Hasil yang baik ditunjukkan oleh pemeliharaan kebersihan gigi tiruan, gigi asli, dan jaringan lunak mulut. Pada pemeliharaan kebersihan gigi tiruan, sebanyak 59 responden membersihkan gigi tiruannya setiap selesai makan, namun terdapat 16 responden responden yang tidak membersihkan gigi tiruan mereka setiap selesai makan, dikarenakan masih kurangnya pengetahuan tentang pentingnya membersihkan gigi tiruan agar terhindar dari masalah kesehatan gigi dan mulut. Pada pemeliharaan kebersihan gigi asli yang masih tersisa serta jaringan lunak mulut memperoleh hasil, sebanyak 63 responden membersihkan gigi asli atau gigi sisa dan jaringan lunak mulut mereka selama 
penggunaan gigi tiruan dan hanya 12 reponden tidak melakukannya. Hal ini dikarenakan sebagian besar responden sudah memiliki kesadaran tentang pentingnya memelihara gigi asli yang masih tersisa beserta jaringan lunak mulut dan sudah menjadi kebiasaan sejak dini, sehingga pemeliharaan kebersihan gigi tiruan dilakukan secara bersamaan saat membersihkan gigi dan jaringan lunak mulut.

Kurangnya tindakan responden juga ditunjukan pada kunjungan ke dokter gigi untuk berkonsultasi mengenai gigi tiruan yang digunakan.Sebanyak 69 responden tidak pernah melakukan konsultasi ke dokter gigi setelah pemasangan dan hanya enam responden yang melakukannya. Hal ini disebabkan karena selain pengetahuan responden yang kurang akan pentingnya melakukan kontrol ke dokter gigi setelah pemasangan gigi tiruan, faktor ekonomi juga berpengaruh terhadap keputusan untuk melakukan kontrol ke dokter gigi. Berdasarkan penelitian yang dilakukan oleh Sarnizia di medan pada tahun 2008, sebanyak $92,5 \%$ responden menyatakan bahwa biaya merupakan faktor yang sangat berpengaruh terhadap pemilihan pelayanan kesehatan khususnya gigi tiruan. ${ }^{20}$ Selain faktor ekonomi, terbatasnya jumlah dokter gigi di daerah tersebut serta jarak yang jauh antara lokasi responden dan tempat praktek dokter gigi merupakan merupakan faktor yang ikut berpengaruh dalam pengambilan keputusan masyarakat untuk melakukan konsultasi ke dokter gigi. Berdasarkan penelitian yang dilakukan di desa Treman tahun 2013 oleh Ayu dan Thirsa, faktor eksternal yang juga berpengaruh terhadap perilaku memilih pelayanan perawatan gigi tiruan yaitu ketersediaannya dokter gigi yang masih minim di daerah Minahasa Utara baik yang bekerja di instansi pemerintah maupun praktek pribadi. ${ }^{11,18}$

Tindakan masyarakat pengguna gigi tiruan lepasan berbasis akrilik yang masih tergolong cukup ini didasarkan oleh pendidikan masyarakat yang rendah, sehingga pengetahuan akan pentingnya memelihara kebersihan gigi tiruan masih kurang. Hal ini dikarenakan seseorang dengan tingkat pendidikan lebih tinggi akan lebih mengerti dan peduli tentang cara memelihara gigi tiruan dan kesehatan rongga mulutnya dibandingkan seseorang dengan tingkat pendidikan rendah. ${ }^{21}$ Berdasarkan penelitian yang dilakukan oleh Briztman di kelurahan Batu Putih Bawah tahun 2014, tingkat pendidikan masyarakat yang rendah sangat berpengaruh terhadap minimnya pengetahuan masyarakat dalam memelihara kebersihan gigi tiruan dan kesehatan rongga mulutnya. Sesorang dengan tingkat pendidikan yang tinggi, memiliki informasi dan pengetahuan lebih banyak termasuk pengetahuan tentang kesehatan gigi dan mulut. $^{22}$

Selain tingkat pendidikan, faktor ekonomi masyarakat juga merupakan faktor yang berpengaruh terhadap tindakan pememeliharaan kebersihan gigi tiruan serta kesehatan rongga mulut. Berdasarkan penelitian yang dilakukan oleh McGrath dan Bedi menyatakan bahwa status ekonomi merupakan prediktor utama yang paling penting bagi seseorang dalam mengambil keputusan untuk melakukan suatu perawatan. ${ }^{23}$ Hal ini sejalan status ekonomi responden yang tergolong menengah ke bawah karena tingkat pendidikan yang rendah. Orang dengan tingkat pendidikan lebih tinggi, umumnya memiliki tingkat ekonomi yang lebih tinggi dibandingkan dengan orang yang tingkat pendidikannya lebih rendah. Hal ini seperti menjadi sebuah batasan bagi orang yang memiliki tingkat pendidikan yang rendah, karena selain mengalami kekurangn dari segi ekonomi mereka juga sulit mendapatkan informasi, pengetahuan, bahkan pelayanan kesehatan yang baik. ${ }^{21}$

Hasil penilaian secara keseluruhan pada ketiga aspek perilaku berdasarkan skor ratarata yang diperoleh, memberikan hasil bahwa perilaku memelihara kebersihan gigi tiruan lepasan berbasis akrilik di desa Treman kecamatan Kauditan tergolong dalam kategori cukup, dimana pada aspek pengetahuan dan tindakan, masyarakat 
pengguna gigi tiruan lepasan berbasis akrilik di desa Treman tergolong dalam kategori cukup dan hanya aspek sikap yang memperoleh kategori baik. Berdasarkan hasil ini maka perlu adanya motivasi dari masyarakat sendiri dalam meningkatkan perilaku memelihara kebersihan gigi tiruan yang digunakannya, terutama dalam mencari informasi untuk menambah pengetahuan serta penerapannya dalam tindakan nyata sehari-hari.Hal ini dilakukan agar perilaku masyarakat dalam memelihara kebersihan gigi tiruan lepasan berbasis akrilik semakin meningkat, sehingga membantu meningkatkan status kesehatan gigi dan mulut masyarakat desa Treman kecamatan Kauditan.

\section{SIMPULAN}

Perilaku memelihara kebersihan gigi tiruan lepasan berbasis akrilik pada masyarakat desa Treman kecamatan Kauditan tergolong dalam kategori cukup.

\section{SARAN}

Bagi masyarakat, berdasarkan hasil penelitian yang diperoleh tentang pengetahuan masyarakat dalam memelihara kebersihan gigi tiruan lepasan berbasis akrilik yang masih tergolong cukup, maka disarankan kepada masyarakat pengguna gigi tiruan lepasan berbasis akrilik di desa Treman agar lebih meningkatkan pengetahuan tentang pememeliharaan kebersihan gigi tiruan.Berdasarkan hasil penelitian tentang sikap masyarakat dalam memelihara gigi tiruan lepasan berbasis akrilik di desa Treman yang sudah tergolong baik, maka diharapkan agar masyarakat pengguna gigi tiruan lepasan berbasis akrilik tetap menjaga dan mempertahankan sikap tersebut dalam memelihara kebersihan gigi tiruan lepasan berbasis akrilik.Berdasarkan hasil penelitian tentang tindakan masyarakat dalam memelihara kebersihan gigi tiruan lepasan berbasis akrilik di desa Treman yang masih tergolong cukup, maka disarankan kepada masyarakat pengguna gigi tiruan lepasan berbasis akrilik agar lebih meningkatkan kesadaran dan kepedulian dalam memelihara kebersihan gigi tiruan lepasan berbasis akrilik, gigi yang masih tersisa, dan jaringan lunak mulut.

Bagi institusi kesehatan, diharapkan adanya kerjasama antara Dinas Kesehatan dan layanan kesehatan setempat dalam penambahan jumlah tenaga dokter gigi dan dokter gigi spesialis, terutama di bidang prostodonsia untuk daerah Minahasa Utara khususnya desa Treman kecamatan Kauditan, agar masyarakat desa Treman dapat memperoleh pelayanan kesehatan gigi dan mulut yang maksimal, khususnya dalam pembuatan gigi tiruan serta mendapatkan edukasi tentang cara memelihara gigi tiruan dari ahlinya untuk memotivasi masyarakat pengguna gigi tiruan lepasan berbasis akrilik dalam memelihara kebersihan gigi tiruan, gigi yang masih tersisa, dan jaringan lunak mulut agar terhindar dari masalah kesehatan gigi dan mulut yang diakibatkan oleh pemakaian gigi tiruan serta meningkatkan kualitas kesehatan gigi dan mulut pengguna gigi tiruan.

Bagi institusi pendidikan, diharapkan adanya penelitian lebih lanjut tentang pemakaian gigi tiruan dengan cakupan lebih luas dan metode yang berbeda, sehingga hasilnya dapat digunakan secara umum untuk pengembangan kesehatan gigi dan mulut khususnya di bidang prostodonsia.

\section{DAFTAR PUSTAKA}

1. Situni JL. Identifikasi faktor penghambat seseorang menggunakan gigi tiruan. EGigi. Universitas Sam Ratulangi. 2013 [diakses 10 Maret 2014]; [6 halaman]. Diunduh dari: URL: http://ejournal.unsrat.ac.id.

2. Aryani. Pemasangan dan pemeliharaan gigi tiruan. Artikel Protodonsia (artikel online), 2010 [diakses 11 Maret 2014]. [32 halaman]. Diunduh dari: URL: http://ocw.usu.ac.id.

3. Gaib Z. Faktor-faktor yang berpengaruh terhadap terjadinya kandidiasis eritematosa pada pengguna gigi tiruan 
lengkap. E-Gigi. Universitas Sam Ratulangi. 2013 [diakses 11 Maret 2014]; [14 halaman]. Diunduh dari: URL: http://ejournal.unsrat.ac.id.

4. Tikker N. Uji daya hambat air jeruk nipis terhadap pertumbuhan candida albicans pada gigi tiruan lepasan akrilik. Dentire Journal. 2012;2(1):124-7.

5. Agtini MD. Persentase pengguna protesa di Indonesia. Media litbang kesehatan. 2010 [diakses 10 Maret 2014]; 2(20):508. Diunduh dari: URL: http://ejournal.litbang.depkes.go.id.

6. Setiawan R. Penatalaksanaan relining pada gigi tiruan sebagian lepasan. Jurnal ilmiah widya. Universitas Prof.DR.Moestopo. 2013 [diakses 11 Maret 2014]; 1(1):60-4. Diunduh dari: URL: http://ejournal.jurwidyakop3.com.

7. Wahyuningtyas E. Pengaruh ekstrak graptophyllum pictum terhadap pertumbuhan candida albicans pada plat gigi tiruan resin akrilik. Indonesian journal of dentistry. Universitas Indonesia. 2008 [diakses 10 Maret 2014]; 15(3):187-91. Diunduh dari: URL: http://www.jdentistry.ui.ac.id.

8. Dikbas I, Koksal T, Bal B, Ozkurt Z, Kazaoglu E. A survey of dentist's attitudes toward cleansing. Oral Health J Turki. 2006 [cited 2014 March 11]; [5 screens]. Available from: URL: http://www.oralhealth.ro/volumes/2006.

9. Am'jad M, Azad AA, Ayub MM, Qureshi MA, Javed M. Denture hygiene habits in complete dentures wearers at Armed Forces Institute of Dentistry. Armed Forces Institute of Dentistry. Pakistan [serial online] 2010; [cited 2014 july 26]; available from: URL: http://www.pafmj.org.

10. Sipayung BI. Kebiasaan memelihara kebersihan gigi tiruan pada masyarakat pemakai gigi tiruan sebagian lepasan di kelurahan Tanjung Rejo kecamatan Medan Sunggal tahun 2012. Skripsi: Fakultas Kedokteran Gigi. Universitas Sumatera Utara. Medan; 2012.

11. Lumunon TO. Faktor determinan perilaku masyarakat dalam pemanfaatan jasa tukang gigi di desa Treman kecamatan Kauditan. E-Gigi. Universitas Sam Ratulangi. 2013 [diakses 11 Maret 2014]; [10 halaman]. Diunduh dari: URL: http://ejournal.unsrat.ac.id.

12. Titjo OC. Perilaku masyarakat pengguna gigi tiruan lepasan di kelurahan Bahu. Skripsi: Fakultas Kedokteran Program Studi Kedokteran Gigi. Universitas Sam Ratulangi. Manado; 2013.

13. Petel IB, Madan G, Patel B, Solanki K, Chavda R. Behaviors and hygiene habits of complete denture wearers in Ahmedabad. J Int Oral Health. India [serial online] 2012; [cited 2014 July 25]; p.30-8. Available from: URL: http://www.ispcd.org.

14. Tarigan S. Pasien prostodonsia lanjut usia: beberapa pertimbangan dalam perawatan. Pidato pengukuhan jabatan guru besar tetap. Universitas Sumatera Utara, 2005. Hal 1-6. [Diakses 25 Juli 2014]. Available form: http://repository.usu.ac.id/bitstream/123 456789/692/1/08E00110.pdf

15. Karniah. Perilaku menjaga kebersihan gigi tiruan dan rongga mulut pemakai gigi tiruan di masyarakat pulau Kodingareng. Dentist Education. Universitas Hasanuddin. [jurnal online] 2012; [diakses 21 Juli 2014]. Diunduh dari: URL: http//repository.unhas.ac.id.

16. Nursalam P. Konsep tingkat pengetahuan. [serial online] 2010 [diakses 26 juli 2014]. Diunduh dari: URL: http://id.shvoong.com.

17. Notoatmodjo S. Promosi kesehatan dan ilmu perilaku. Jakarta: Rineka cipta; 2007.h.133-51.

18. Angraeni A. Persepsi masyarakat terhadap pembuatan gigi tiruan oleh tukang gigi di Desa Treman Kecamatan Kauditan. E-Gigi. Universitas Sam Ratulangi. 2013 [diakses 23 Juli 2014]; [10 halaman]. Diunduh dari: URL: http://ejournal.unsrat.ac.id.

19. Peracini A, Andrade IM, Paranhos HFO, Silva CHL, Souza RF. Behaviours and hygiene habits of complete denture 
wearers. Braz Dent J 2010; 21(3): 24752.

20. Meutuah S. Hubungan karakteristik pengguna gigi palsu dengan pemanfaatan jasa tukang gigi di kota Medan tahun 2008. [Skripsi]. USU Repository [serial online] 2008; [diakses 27 juli 2014]. Diunduh dari: URL: http://repository.usu.ac.id.

21. Lidan R, Rahmayani L, Hikmah YL. Hubungan jenis kelamin dan tingkat pendidikan terhadap penggunaan gigi tiruan sebagian lepasan di praktek dokter gigi spesialis prostodonsia. Cakradonya Dent J 2011. Hal. 332-39.

22. Manapawang BN. Gambaran pemeliharaan kebersihan GTL akrilik pada masyarakat kelurahan batu putih bawah. E-Gigi. Universitas Sam Ratulangi. 2014 [diakses 22 Juli 2014]; [10 halaman]. Diunduh dari: URL: http://ejournal.unsrat.ac.id.

23. McGrath C, Bedi R. Severe tooth loss among UK Adults-who goes for oral rehabilitation?.J Oral Rehabil. 2002; 29:240-4. 